\title{
Resertch Article: Economic comparison of direct seeded rice (DSR) and transplanted rice cultivation in TBP command area of Karnataka
}

\section{Y. MANOHAR, B. NIRMALA AND K. SUHASINI}

Article Chronicle: Received :

17.07.2017;

Accepted :

01.08.2017

KEY Words:

Direct seeded rice, Transplanted rice, TBP

Author for correspondence :

\section{Y. MANOHAR]}

Department of

Agricultural Economics, College of Agriculture,

Professor Jayashankar

Telangana State

Agricultural University,

Rajendranagar,

HYDERABAD

(TELANGANA) INDIA
SUMMARY : The present study was conducted in Koppal, Bellary and Raichur districts in TBP command area of Karnataka with the objectives to estimate and compare the costs and returns for direct seeded rice and transplanted methods of paddy cultivation. A total of 90 sample paddy growing farmers were selected by adopting purposive random sampling technique. The total cost of cultivation of paddy under DSR was found to be lower by 15.39 per cent (Rs.73661.1/ha) when compared to TR (Rs.87061.5/ ha) method of cultivation. The cost concepts revealed that according to cost $\mathrm{A}_{1}$, maximum costs were incurred for the transplanted rice (Rs.62548.6/ha) than that of direct seeded rice (Rs.50045.6/ha). The cost $B_{1}$ for transplanted rice (Rs.62863.6/ha) was slightly higher than direct seeded rice (50330.1/ha). The average yield was considerably high in DSR (64.18 qtl/ha) compared to TR (56.79 qtl/ha) method of cultivation. The gross returns obtained were Rs.1,36,127 and Rs.1,19,755 per ha for DSR and TR of rice cultivation respectively. The net returns were higher in DSR (Rs.62465/ha) than that of TR (Rs.32693/ ha), this was due to high cost of cultivation in transplanted rice. Returns per rupee spent was higher in DSR (1.85), when compared with TR (1.38).

How to cite this article : Manohar, Y., Nirmala, B. and Suhasini, K. (2017). Economic comparison of direct seeded rice (DSR) and transplanted rice cultivation in TBP command area of Karnataka. Agric. Update, 12(TECHSEAR-6) : 1705-1709; DOI: 10.15740/HAS/AU/12. TECHSEAR (6)2017/1705-1709. 